\title{
Statistics and Countermeasures on the Risk of Poverty Alleviation of Farmers in the Poor Area
}

\author{
Xiaojun $\mathrm{Pan}^{1}$, Chengyi $\mathrm{Pu}^{2, *}$ \\ ${ }^{1}$ Xiaojun Pan. School of Economics, Southwest University for Nationalities, Email: 1002343190@qq.com \\ ${ }^{2}$ Chengyi Pu, School of Insurance, Central University of Finance and Economics, \\ * Corresponding author. Email: pucy@cufe.edu.cn
}

\begin{abstract}
The western ethnic regions are typical areas of deep poverty in our country. The main reasons for the high incidence of poverty are the loss or lack of income-increasing opportunities and ability of farmers due to multidimensional risks such as endemic diseases, disasters, and lack of education. Multi-dimensional risks have led to insufficient development motivation of farmers and hindered family production and business activities, leading to insecure household income of farmers, and it has become a common phenomenon to cause (return) poverty due to illness (disaster). Existing researches rarely analyze the inherent relationship between the risks faced by farmers and their income channels and the degree of poverty. This paper takes the poor peasant households in 18 ethnic villages in the western ethnic regions as a sample, and conducts a questionnaire survey in the form of on-site interviews with the main labor force or the head of the household. Through descriptive statistics and multiple regression model analysis, it is found that there is a significant correlation between the status of farmers, the risks they face in their main income channels, and different levels of poverty. The level of education, health, and labor skills have different effects on farmers with different levels of poverty. Agricultural production and sales barriers, agricultural disasters, environmental disadvantages, insecure wages and construction periods for migrant workers, accidental injuries and other risks that affect farmers' income also have significant differences in the impact of different levels of poverty. Following the design concept of "industry cultivation is the foundation, increasing residents' income is the core, a better life is the goal, and risk management is the soul", the industrial risk chain of "eco-fragile-frequent disasters-production difficulties" and "emergency diseases-" Falling into poverty-loss of labor" health risk chain, through the builtin financial insurance model innovation, coordinated with the adjustment of the organization system optimized by the coordination mechanism of the stakeholder relationship, the formation of "financial insurance support + household health + industrial development" "industrial poverty alleviation + health poverty alleviation + " The multi-dimensional development model of "educational poverty alleviation + insurance poverty alleviation" increases residents' income, improves people's lives, improves residents' health, promotes rural revitalization, and realizes a well-off society in an all-round way.
\end{abstract}

Keywords: risk of poverty, poverty level, precise poverty alleviation

\section{深度贫困区农户致贫风险统计与对策研究}

\author{
潘小军 $^{1}$ 蒲成毅 $^{2, *}$
}

\author{
1. 潘小军. 西南民族大学经济学院, 成都, ZC. 610041 \\ 2. 蒲成毅. 中央财经大学保险学院, 北京市海淀区学院南路 39 号, 北京, ZC. 100081 \\ * 通讯作者. 电子邮箱: pucy@cufe.edu. cn
}

\begin{abstract}
摘要：西部民族地区是我国典型的深度贫困区域, 地方性疾病、灾害、缺少教育等多维风险致使农户家庭丧失 或缺少增收机会和能力是贫困发生率高的主要原因。多维风险致使农户自身发展动力不足和家庭生产经营活 动受阻导致农户家庭收入无保障, 因病（灾）致（返）贫成为常见现象。现有研究鲜有从农户自身状况和收入 渠道两个方面面临的风险与贫困程度的内在联系的分析。本文以西部民族地区的 18 个民族村寨的贫困农户家 庭为样本, 对家庭的主要劳动力或户主做实地访谈形式的问卷调查。通过描述统计与多元回归模型分析, 发现 农户自身状况、主要收入途径中面临的风险与不同程度贫困间存在显著相关性，受教育水平、健康状况、劳动 技能水平对不同程度贫困的农户影响不同。农业生产销售障碍、农业灾害、生态环境劣势、外出务工的工资和 工期无保障、意外伤害等影响农户收入的风险对不同程度贫困的影响也存在显著差异。遵循“产业培育是根本，
\end{abstract}


居民增收是核心，美好生活是目标，风险管理是灵魂” 的设计理念，围绕农户家庭 “生态脆弱-灾害频发一生产 困难” 产业风险链，以及 “疾病突发一陷入贫困-丧失劳力” 健康风险链，通过内置金融保险模式创新，配合利 益主体关系协调机制优化的组织制度调整，形成 “金融保险支持+家居民健康+产业发展” 的 “产业扶贫+健康 扶贫+教育扶贫+保险扶贫” 多维结合的发展模式，增加居民收入，改善群众生活、提高居民健康，推进乡村振 兴, 实现全面小康。

关键词：致贫风险，贫困程度，精准扶贫

\section{1. 绪论}

\section{1. 研究背景}

贫困是乡村振兴与全面小康的障碍, 党和政府高 度重视, 全力以赴, 持之以恒, 全国贫困人口大幅减少, 绝对贫困逐步得到解决, 但相对贫困逐渐突出, 西部民 族地区最为典型。但是, 面临的不只是灾害与经济社会 风险, 而是 “生态环境脆弱风险一自然灾害频发风险一 农户生计艰难风险一居民深度贫困风险一农村精英独 占风险一集体经济薄弱风险一乡村衰落消失风险一社 会发育滞后风险一城乡市场割裂风险一社会和谐稳定 风险” 等多重风险叠加振荡的反复侵害的恶性循环的 可能, 加剧政府、市场、企业、村社与农户的多方关系 冲突和嬗变, 这既是全面小康社会后的 “硬伤”, 也是 后脱贫时代西部民族地区如何巩固脱贫成果和防止返 贫的 “隐患”。

\section{2. 目的意义}

西部民族深度贫困地区农户往往面临多维风险造 成的多维贫困，且不同致贫风险对不同贫困程度的农 户的影响程度不同。致贫风险包括农户自身风险因素 (例如教育水平低、健康状况差、劳动技能水平低) 和 主要收入途径中的致贫风险 (农业生产多维度受限; 外 出务工工资、工期无保障; 人身意外伤害等)。

本研究遵循“产业培育是根本, 居民增收是核心, 美好生活是目标, 风险管理是灵魂” 的设计理念, 围绕 农户家庭“生态脆弱一灾害频发一生产困难”产业风险链, 以及 “疾病突发一陷入贫困一丧失劳力” 健康风险链, 叠 加引发 “生计困难-经济贫困-乡村衰落-城乡割裂-社 会失衡” 的经济社会风险, 通过内置金融保险模式创新, 配合利益主体关系协调机制优化的组织制度调整, 形 成 “金融保险支持+家居民健康+产业发展” 的 “产业扶 贫+健康扶贫 + 教育扶贫 + 保险扶贫” 多维结合的发展模 式, 形成 “生态恢复一防灾减灾一生计改善一居民增收 一经济发展一乡村振兴一城乡平衡一社会稳定” 的脱
贫新路径, 增加居民收入, 改善群众生活、提高居 民健康，推进乡村振兴，实现全面小康。

\section{3. 文献综述}

改革开放四十年来，我国已经处于历史与经济 发展的新时代, 但是全球发展不平衡, 我国东西部 发展不平衡, 城乡发展不平衡的问题还仍未解决。 而西部深度贫困地区的环境恶劣、经济落后等问题 尤其严重 ${ }^{[1]}$, 现在改善这些问题的关键就在于如何 缓解深度贫困地区经济状况 ${ }^{[2]}$ 。贫困人口是全面建 成小康社会的最大 “短板”, 因病致贫在所有的致贫 因子中，（因病致贫约为 42\%，因灾致贫为 $20 \%$ ，因 教育致贫的 $10 \%$, 因劳动能力弱致贫的有 $8 \%$, 其他 原因致贫的约为 20\%）居于首位。所以解决贫困人 口的看病问题是重中之重。

新农合为了解决我国农民群体 “看病难, 看病 贵” 的问题，有效缓解了一人得病全家遭殊的困境。 统计表明，从 2004 年到 2017 年参加新农合人数从 0.8 亿增到 2.75 亿，参合率从 $75.2 \%$ 上升至 $99.36 \%$, 基本实现全覆盖。但是, 在经济转轨与社会转型的 新时代下, 要实现全面小康社会, 仅仅依靠新农合 的作用是远远不够的。

目前, 研究新农合相关文献主要分三种, 一是 通过定义相关衡量指标衡量新农合的缓解因病致 贫的效果, 发现我国新农合缓解效果比较显著; 二 是通过分层抽样调查访谈方式获得实时信息，发现 我国新农合并没有起到预期效果；三是是利用中国 健康与营养调查数据进行回归分析, 得出新农合缓 解因病致贫的效果不显著。

在多年的扶贫过程中，发现农业保险扶贫能够 放大扶贫资金政策效果，农业保险促进农业生产， 帮助农民提高农业经营收入 ${ }^{[3]}$ 。但是, 面对 “贫穷+ 灾害” 而采取的 “补贴+救济”, 财政压力较大, 急 需拓宽扶贫资金来源，增多扶贫力量 ${ }^{[4]}$ 。农业保险 可以保障贫困农户生产和生活免遭自然灾害和意 外事故所带来的经济损失, 利用农业保险进行精准 扶贫, 能够精准对接不同贫困农户风险保障的差异 
化需求, 有效地降低了农民因灾致贫的可能性, 在精准 分散贫困农户风险的同时，又改善了贫困地区因灾致 贫、因灾返贫的现象 ${ }^{[5]}$, 在保障农户收入的同时可以提 高农户种植积极性, 促进地区农业的发展, 进而使得贫 困地区实现摘帽, 贫困农户实现脱贫, 有利于社会的安 定和谐、长治久安, 减轻政府救灾支出, 降低了财政压 力 $^{[6]}$ 。

显然, 农业保险精准扶贫具有识别、帮扶、考核精 准等突出特点, 是我国扶贫工作的一大创新与突破。保 险赔偿农户生产中遭遇风险的损失，通过扶持产业活 动稳定农户收入, 改变传统粗放式的扶贫模式, 改变了 传统 “补贴扶持+救济救助” 的政府单一 “输血”, 形成 “政府主导、多主体联合” 的 “补贴扶持+救济救助+保 险赔偿” 的 “造血” 可持续脱贫能力。

综上所述, 许多学者在劳动力转移、脱贫方面进行 了卓有成效的研究, 为我们对农村人力资本开发研究 留下了宝贵经验, 为本次研究奠定了重要的理论基础。 与前人研究相比, 本次研究与之不同之处主要包括: 第 一, 在研究对象上, 很多前人研究农村遭遇的单方面 致贫风险因素, 但在现实中, 很多农村, 特别是西部深 度贫困民族地区, 往往面临多维致贫风险因素加剧了 农户的贫困程度; 第二, 不同程度的贫困农户面临不同 的致贫风险，不同致贫风险的致贫可能性和程度也不 相同。在前人的研究基础上, 本次研究以问卷调查和实 地访问的方式, 调查统计研究地区劳动力生产活动面 临的风险，通过描述统计西部深度贫困民族地区劳动 力生产发展活动受阻的常见风险因素, 由建模分析该 地区不同贫困程度的农户面临的主要致贫风险, 并提 出对应的改进措施, 改善西部深度贫困民族地区多维 贫困现状, 助力脱贫攻坚和乡村振兴。

\section{2. 问卷调查结果描述统计}

\section{1. 调查样本基本发展状况}

\section{（1）楚雄州经济发展状况}

楚雄州地处云南省中部, 楚雄彝族自治州是云南 省下辖的自治州, 东与昆明市交界, 南与普洱市、玉溪 市毗邻, 西与大理白族自治州接壤, 北与四川省攀枝花 市相连, 通达四川。面积为 2.9 万平方公里, 辖一个市 九个县。

楚雄彝族自治州境内多山, 山地面积占总面积 90\% 以上, 州内山峰连绵, 谷地错落, 溪河纵横, 养育出多 个少数民族, 创造了丰富多彩的少数民族文化。据统计,
州内居住着彝族、苗族、傈傈族、回族、白族、哈 尼族、傣族和汉族等 25 个民族, 其中彝族人口占总

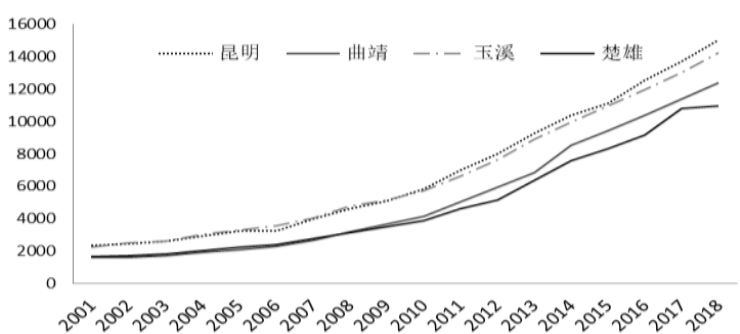

人口的 $25.17 \%$ ，占少数民族人口的 $80.82 \%$ 。万人以 上少数民族有彝族、傈傈族、苗族、傣族、回族和 白族。

图 1 滇中城市圈农村常住居民人均纯收入 数据来源: 云南省历年统计年鉴 (单位: 元)

如图 1 所示, 自 2001 年以来, 滇中城市经济圈 农村常住居民人均纯收入总体呈上升趋势，且增长 速度越来越大。但自 2009 年以来, 楚雄州农村常住 居民人均纯收入与其他三个城市差距越来越明显, 且增长趋势较为平缓。数据显示, 楚雄州农村常住 居民人均纯收入较其他三个滇中城市明显偏低，农 村整体经济水平在滇中城市经济圈相对落后。

云南省滇中城市经济中，楚雄彝族自治州农村 经济水平低, 且发展缓慢。促成该现状的主要原因 是州内县城农村发展落后, 深度贫困聚集。很多农 村经济发展落后和缓慢是由地理环境、人文环境和 历史因素共同造成的。州内的深度贫困区多集中在 民族村寨, 受交通条件限制, 加上自然环境不适宜 种植, 稳产高产面积少, 大部分地区难以实现农村 经济作物产业化; 地区民族成分复杂，人口少，多 样的民族文化充满特色但发展力量薄弱; “势单力 薄” 的民族文化作为独立的特色文化产业发展，资 金扶持力度小，市场难开拓，开发方法不对，易导 致劳民伤财，支撑难以持续，大力传承弘扬各民族 文化的同时还要求保护好各少数民族文化的原生 态，特色文化产业发展充满挑战; 加之早期国家集 中精力发展东部地区经济, 使得西部地区经济起步 落后许多。

\section{（2）楚雄州农村贫困劳动力现状}

截至 2018 年 5 月底, 全州信息库中共有 18.29 万农村贫困劳动力信息, 占全州贫困劳动力总数的 $81.46 \%$ ，在上年基础上共计更新补录数据 1.51 万 条。目前实现转移就业, 按行业分布划分: 第一产 业占 $21.69 \%$ ，第二产业占 $21.45 \%$ ，第三产业占 $56.86 \%$; 按从业去向划分：乡（镇）上就业人数占 
表 1 禄丰峨山贫困农户问卷调查描述统计表

\begin{tabular}{|c|c|c|c|c|c|c|c|}
\hline 类别 & 分类指标 & 绝对数值 & 百分比 & 类别 & 分类指标 & 绝对数值 & 百分比 \\
\hline \multirow{3}{*}{ 民族 } & 少数民族 & 586 & 90.2 & \multirow{3}{*}{$\begin{array}{l}\text { 贫困农户人 } \\
\text { 均收入 }\end{array}$} & $3500-4000$ & 200 & 30.8 \\
\hline & 汉族 & 64 & 9.8 & & $3000-3500$ & 297 & 45.7 \\
\hline & 文盲或半文盲 & 68 & 10.4 & & 3000 及以下 & 153 & 22.5 \\
\hline \multirow[t]{3}{*}{ 文化程度 } & 小学 & 342 & 52.7 & \multirow{3}{*}{$\begin{array}{l}\text { 资金储蓄状 } \\
\text { 况 }\end{array}$} & 有一定资金 & 36 & 5.6 \\
\hline & 初中及以上 & 240 & 36.9 & & 无资金储蓄 & 380 & 58.8 \\
\hline & 健康 & 477 & 73.5 & & 负债 & 231 & 35.6 \\
\hline \multirow[t]{2}{*}{ 健康水平 } & 长期慢性病 & 108 & 16.6 & \multirow{3}{*}{ 人均稳产面 } & 一亩及以下 & 460 & 70.7 \\
\hline & 残疾 & 65 & 9.9 & & $1-2$ 亩 & 102 & 15.7 \\
\hline \multirow[t]{3}{*}{ 劳动技能水平 } & 无劳动能力 & 18 & 2.44 & & 2 亩及以上 & 88 & 13.6 \\
\hline & 一般劳动技能 & 539 & 82.93 & \multirow{3}{*}{$\begin{array}{l}\text { 农业生产主 } \\
\text { 要风险 }\end{array}$} & 销售无保障 & 260 & 40.1 \\
\hline & 特殊劳动技能 & 93 & 14. 36 & & 气象灾害 & 197 & 30.3 \\
\hline \multirow{2}{*}{ 主要收入来源 } & 农业生产 & 393 & 60.4 & & 发展环境劣势 & 132 & 20.4 \\
\hline & 外出务工 & 200 & 30.5 & \multirow{3}{*}{$\begin{array}{l}\text { 外出务工主 } \\
\text { 要风险 }\end{array}$} & 工资拖欠 & 292 & 44.9 \\
\hline 外出务工资源获 & 政府牵头 & 63 & 9.76 & & 工期无保障 & 208 & 32.1 \\
\hline 得方式 ～～～～ & 其他私人联系 & 586 & 90.24 & & 意外伤害 & 133 & 20.5 \\
\hline
\end{tabular}

$38.69 \%$; 县内城乡间就业占 $15.83 \%$; 州内县外就业人数 占 $15.71 \%$; 省内州外就业占 $18.52 \%$; 省外国内就业占 $11.02 \%$; 境外就业占 $0.23 \%$ ) 累计实现贫困劳动力转移 就业占全州贫困劳动力总数的 $52.52 \%$ 。

\section{（3）深度贫困民族地区禄丰峨山概况}

峨山村委会位于云南省楚雄彝族自治州禄丰县中 村乡, 属于山区。距离中村乡镇约 30 公里, 国土面积 为 40185 平方公里, 平均海拔 1806 米, 适宜种植核桃、 包谷等农作物。该村委会有耕地 1014 亩, 其中人均耕 地 0.98 亩; 林地面积为 38913 亩。全村委会共 18 个 村民小组, 有乡村人口 1124 人, 其中农业人口 1147 人, 劳动力 612 人, 其中从事第一产业人数 537 人, 收入 主要以种养殖业、核桃为主。

峨山这样的深度贫困民族地区具有普遍的劣势特 征: 居住条件恶劣, 交通条件落后, 稳产和高产面积几 乎为零, 民风淳朴, 教育落后, 年轻劳动力流失严重, 农 村老幼病弱残群体医疗及其他保障缺乏, 家庭经济来 源单一, 资金储备不足等, 经济基础薄弱使得这些贫困 家庭难以承受普通的变故, 因灾、因病致贫和返贫在这 些深度贫困区随处可见。

\section{2. 问卷调查统计分析}

\section{（1）样本选择与数据来源}

2019 年 8 月暑假对云南省楚雄彝族自治州禄丰县 峨山村委会 18 个村寨进行问卷调查和实地访问, 对少 数民族农村劳动力发放问卷。调查采用等额概率抽样 的方法, 以入户结构式进行问卷访问, 并对该部分农民 家庭户主进行深度访谈, 对农村的家庭劳动力进行随 机抽取进行问卷回答, 共发放问卷 680 份, 回收 665 份。 其中, 剔除无效问卷 15 份, 获得有效问卷 650 份。

\section{（2）问卷调查统计表}

本次研究通过对样本风险因素进行统计描述, 了解研究地区贫困劳动力的教育、健康、劳动技能 等状况; 主要生产经营活动 (农业生产和外出务工) 的制约 (风险) 因素。

\section{（3）贫困农户教育和健康水平}

该村委会约有 $10 \%$ 的贫困农户为文盲或半文盲， 超过 50\%为小学文化程度, 36. 9\%的贫困农户受过初 中及以上教育, 其中受大专和高中教育的仅约为 $3.1 \%$ 。农村贫困劳动力的教育程度普遍偏低, 教育 程度偏低, 一定程度上, 表明接受和学习新事物的 能力较差, 劳动力整体素质较差。约 $80 \%$ 为健康水平, 15\%患长期慢性病, 残疾比例为 $5 \%$, 健康风险直接 制约劳动力生产发展能力。

\section{（4）贫困农户劳动技能水平和资金储蓄状况}

约有 $2.4 \%$ 的劳动力无法参加生产活动, 约有 82. 93\%为普通劳动技能, 特殊技能占比为 $14.7 \%$ 。 无劳动能力的农户意味着缺失最基本的生存能力, 普通劳动技能难以适应新时代的农业发展, 收益和 经济价值低, 由此可见, 整体偏低的劳动技能水平 应该是阻碍农村健康劳动力生产发展创收的重要 因素。

资金储备状况指劳动力的资金储蓄、借贷情况， 在脱贫过程中，资金储备状况往往决定了一个家庭 脱贫能力的薄弱。无资金储蓄比例占样本比例达 $58.8 \%$ ，负债则达到 $35.6 \%$ ，有一定资金储备的比例 仅为 $5.6 \%$ 。资金储备能力薄弱, 农户缺乏资金进行 创业、规模种植、从商等活动, 偏低的年收入增加 了农民还贷压力, 高比例持续的贷款拖欠还可能给 农村金融机构带来风险。

\section{（5）收入途径和外出务工资源获得方式}

当地贫困农户从事农业生产活动占比达 $60.4 \%$, 
外出务工比例达 $30.5 \%, 9.1 \%$ 依靠其他途径获得生活所 需费用。因此, 研究地区贫困农户的主要收入途径是农 业生产和外出务工。以外出务工获得主要收入的贫困 农户中，仅约有 9.8\%的贫困农户由政府帚头商谈，超 过 $80 \%$ 的贫困农户依靠私人联系寻找。外出务工资源获 得渠道不明朗会产生一系列致风险, 例如工作内容、工 期不明确, 工资无保障等。

\section{（6）贫困农户主要收入途径面临风险}

村委会贫困劳动力普遍至少面临着两个以上的致 贫风险因素, 且劳动力主要致贫风险因素不尽相同。统 计贫困农户主要收入获得途径中的风险因素, 超过 35\% 的贫困农户认为农业生产的主要致贫风险是发展环境 劣势, 例如土地贫瘦、交通闭塞、居住地地势有塌陷危 险等, 发展环境劣势使得农产品单一、输送不方便、市 场信息滞后、外商引进困难。约 40\%的贫困农户认为农 业生产的主要风险是销售无保障, 销路和价格无保障 增加了农户从事农业生产的顾虑, 降低了农户的预期, 最终导致农户生产规模减小, 产量减小。农产品收割后, 易因销路不通畅而滞销或产品价格低廉而致使农民收 入减少或亏损。约 20\%的贫困农户认为从事农业生产的 主要风险为农业气象灾害。当地的主要农作物是玉米、 核桃和烤烟, 但由于冰雱、干旱、泥石流等气象灾害, 农业生产易遭受损失。当地农户的另一大收入途径是 外出务工。经问卷调查, 劳动力外出打工大多依靠私人 联系寻找, 充满不确定因素, 例如出现工费不合理、工 作内容不明确、霸王条款等风险。在外出打工过程中, 拖欠工资的风险概率最高, 约达 45\%, 其次为意外伤害, 超过 $32 \%$, 由于劳动技能水平低, 大部分劳动力从事建 筑、道路、管道、风力发电机等工程建设, 其危险性较 高, 意外风险大, 但由于教育条件相对落后及维权意识 薄弱, 很多劳动力并无为自己争取安全保障的意识。主 要风险因素为工期无保障, 比例约为 $20 \%$ 。很多外出务 工人员并没有进行合同签订和正规的商议, 工期等事 项无保障。外出务工是当地主要经济收入来源之一, 完 善的外出劳务保障是确保劳动力脱贫增收的重要举措。

\section{（7）贫困农户人均收入}

本次调查中将不同收入状况分为三个等级, 人均 收入为 3500-4000 元的等级为普通贫困, 占比为 30. 8\%, 人均收入为 3000-3500 元的等级定为一般贫困, 占比 为 $45.7 \%$, 将人均收入在 3000 元及以下等级定为特别 贫困等级, 占比为 $22.5 \%$ 。

\section{3. 贫困农户致贫风险计量分析}

\section{1. 影响因素选取与研究设计}

\section{1. 1. 研究指标选取}

农村贫困的表层原因多是疾病、灾害、教育等, 但究其根本原因是农村劳动力缺少脱贫增收的机 会和能力。造成该现象的原因主要包括两个方面, 一是农村劳动力自身发展动力不足, 包括文化程度 跟不上、健康状况差、劳动技能水平低; 二是农户 主要收生产经营活动多维受阻, 主要收入来源无保 障甚至高损失风险率直接加剧了农户贫困的可能 性和程度。

劳动力贫困程度常见指标为农户人均收入水 平, 家庭贫困往往是多维致贫因素结果。本次以劳 动力贫困程度为因变量, 选取几个深度贫困区常见 的内外致贫因素进行研究。深度贫困民族地区的劳 动力生产发展受阻, 受自身风险因素和外在风险因 素限制。自身因素主要为劳动力健康水平、教育程 度、劳动技能水平等。外在风险因素主要包括外出 务工风险因素 (人身意外、工资拖欠、工期无保障 等) 和农产品发展风险因素 (气象灾害、价格无保 障、发展环境劣势等)。

农村保留了较为传统的农村经济发展模式, 特 别是深度贫困地区, 与外界联系少, 交通闭塞, 教 育程度偏低, 劳动（简单劳动）成为最基本的发展 生产方式。农户家庭负担主要源于家庭非健康人口 与非劳动力人口。研究显示, 贫困户非健康人口比 例均显著高于非贫困户，这表明贫困户面临更大的 家庭负担约束。家庭经济是农户生存、发展的基础, 而劳动力自身健康水平往往决定了农村家庭生产 能力的强弱, 健康水平越低, 劳动力贫困可能性和 程度越高。农村人力资本和物力资本是农村经济发 展的生产性资本，通过教育可调节当前劳动力市 场供求不平衡的局面。外出务工和农业产业化发展 成为越来越多农户的谋生之路, 教育显得越来越重 要, 劳动力教育程度偏低, 农村劳动力学习能力退 化, 接收新事物的能力减弱。根据经验和相关研究, 教育程度越高, 劳动力生产能力和自我提高能力越 强, 收益效率越高, 贫困程度越低。

农村劳动力整体素质水平低已成为制约农民 经济发展和当地经济发展的重要因素。要提高劳动 力素质水平, 首先要提高农村劳动力技能水平, 为 
乡村振兴战略的全面协调发展提供充分的人力资源。 无论是外出务工还是在农村发展生产活动, 劳动力高 技能水平往往是提高其生产效率、创造高收益的形式。 因此, 劳动力的技能水平应该与劳动力贫困程度成负 相关, 即劳动技能水平越高, 劳动力贫困程度就越低。

农民工权益保障制度不完善，对相关政策了解甚 少, 维权意识薄弱, 特别是很多劳动力从事建筑、铺路、 风力发电等工作, 危险性极高, 不知如何保护自己和降 低事后风险。农民进城镇工作的权益保障，直接关系到 农户的切身利益，关系到国家经济发展、政治稳定与 社会和谐。因此, 农村劳动力外出务工的人身意外是致 使劳动力贫困的重要因素。人身意外风险越大, 致贫可 能性和程度越大。外出务工的农民最担心的问题之一 是工资问题。农民工没有从事投资经营的知识和资本, 文化水平较低, 只能从事那些体力劳动为主的工作, 特别是那些 “累、脏、险” 的活，而工资却与工作量不 成正比。农民工的廉价劳动力很多缺乏合同协议保障, 拖欠农民工工资、工期无保障成为了农民工问题中非 常普遍的顽疾。

在农产品经济发展过程中, 农业种植受气象灾害
影响, 农作物产量、质量降低。气象灾害往往成为阻 碍农业生产，经济发展的重要因素。我国农产品价 格总是存在大幅波动现象, 销路和价格严重影响农 民的切身利益, 由于农产品的特殊性，易出现谷贱 伤农的现象，而在未丰收时节，收入也因产量少而 减少，收入减少直接导致家庭经济出现问题，加剧 贫困程度。由此分析，销售无保障是致使农村劳动 力贫困程度加剧原因之一。

\section{1. 2. 研究设计}

本次研究通过描述统计得出研究地区贫困农 户面临的主要致贫风险，通过 logistic 多元回归 模型分析各致贫风险与不同程度的贫困的相关性 和重要性，并制定对应的政策措施，帮助政府瞄准 帮扶目标, 助力精准扶贫, 精准脱贫。

将研究地区农户贫困程度设为被解释变量, 将 主要几个风险因素视为解释变量进行分析（如表 2 所示)。

表 2 变量定义

\begin{tabular}{cccc}
\hline \multicolumn{2}{c}{ 统计指标 } & 变量 & 变量取值 \\
\hline 劳动力贫困程度 & & $\mathrm{Y}$ & 特别贫困 $=1 ;$ 一般贫困 $=2$; 普通贫困 $=3$ \\
主要收入方式 & 农业生产风险 & $X 1$ & 销售无保障 $=1 ;$ 气象灾害 $=2 ;$ 发展环境劣势 $=3$ \\
& 外出务工风险 & $X 2$ & 工作拖欠 $=1 ;$ 工期无保障 $=2$; 意外伤害 $=3$ \\
劳动力自身因素 & 教育水平 & $X 3$ & 文盲或半文盲 $=1$; 小学 $=2$; 初中及以上 $=3$ \\
& 劳动技能水平 & $X 4$ & 特殊劳动技能 $=1 ;$ 一般劳动技能 $=2$; 无劳动技能 $=3$ \\
& 健康状况 & $X 5$ & 健康 $=1 ;$ 长期慢性病 $=2 ;$ 残疾 $=3$ \\
\hline
\end{tabular}

（1）多元有序回归模型建立

本文根据问卷调查将贫困农户收入水平分为普通 贫困、一般贫困和特别贫困三个次序，贫困程度依次 加深。因此，应该运用有序多分类模型。模型研究何 种因素影响加剧了贫困农户程度, $p_{j}=p(y \leqslant j \mid x)$ 为 $y$ 取前 $\mathrm{j}$ 个值的累积概率。

$\log i t\left(p_{j}\right)=\ln \left(\frac{p_{j}}{1-p_{j}}\right)=\alpha_{j}+\beta_{1} x_{1}+\beta_{2} x_{2}+\cdots+\beta_{n} x_{n}$

\section{（2）模型拟合度检验}

对模型整体拟合进行检验。由表 3 可知, 在加入 各因变量后，模型的 -2 倍对数似然值从 124.585 下降 到 49.999, P 值为 0.000 , 小于 0.05 , 说明该模型拟 合较好。平行性检验中显著性大于 0.05 , 从侧面证明
因变量中普通贫困、一般贫困、特别贫困是等 差关系，模型中的参数估计值是有效的（表 4)。

表 3 模型拟合信息

\begin{tabular}{|c|c|c|c|c|}
\hline 模型 & -2 对数似然值 & 卡方 & $\mathrm{df}$ & 显著性 \\
\hline 仅截距 & 124.585 & & & \\
\hline 最终 & 49. 999 & 42. 178 & 7 & 0.000 \\
\hline \multicolumn{5}{|c|}{ 表 4 平行性检验 } \\
\hline 模型 & -2 对数似然 & 卡方 & 自由度 & 显著性 \\
\hline 原假设 & 49.999 & & & \\
\hline 常规 & $46.324 \mathrm{~b}$ & $3.675 \mathrm{c}$ & 5 & .597 \\
\hline
\end{tabular}


表 5 多元有序 Logistic 回归结果

\begin{tabular}{cccccccc}
\hline 变量 & 分类指标 & \multicolumn{3}{c}{ 一般贫困 } & & \multicolumn{3}{c}{ 特别贫困 } \\
\hline \multirow{2}{*}{ 农业生产风险 } & & 回归系数 & P 值 & OR 值 & 回归系数 & P 值 & OR 值 \\
& 销售无保障 & 1.194 & 0.000 & 1.905 & 2.302 & 0.000 & 2.302 \\
外出务工风险 & 发展环境劣势 & 1.353 & 0.001 & 1.325 & 0.784 & 0.034 & 1.012 \\
& 工资拖欠 & 0.675 & 0.037 & 2.121 & 0.004 & 0.325 & 1.037 \\
劳动技能水平 & 工期无保障 & 0.842 & 0.12 & 0.325 & 0.012 & 0.024 & 0.824 \\
& 一般劳动技能 & -0.158 & 0.108 & 0.001 & -0.023 & 0.003 & 1.327 \\
& 特殊劳动技能 & -1.734 & 0.002 & 1.156 & -0.961 & 0.012 & 1.038 \\
健康水平 & 健康 & -0.009 & 0.041 & 0.612 & -0.365 & 0.001 & 1.325 \\
& 残疾 & 0.017 & 0.066 & 0.782 & 0.263 & 0.016 & 1.378 \\
教育水平 & 小学 & -0.151 & 0.265 & 0.012 & -0.248 & 0.482 & 0.030 \\
& 初中及以上 & -0.757 & 0.043 & 1.376 & -0.096 & 0.038 & 1.586 \\
\hline
\end{tabular}

数据来源：SPSS 数据分析，显著性水平为 $5 \%$ 。

\section{1. 3. 研究结果分析}

本次回归将普通贫困农户设为参考对象, 因此其 系数为零, 将一般贫困和特别贫困农户与其对比进行 回归, 将自变量中农业生产风险中的气象灾害、外出 务工中的意外伤害、劳动技能水平中的无劳动技能、 健康水平中的长期慢性病、教育水平中的文盲及半文 盲分别设为参对应的参考对象, 回归系数符号表示自 变量与因变量的正负相关性, 其绝对值表示自变量对 因变量的影响程度。

表 5 为本次多元有序回归模型结果。从农业生产 风险来看, 销售无保障中, 一般贫困和特别贫困的系 数分别为 1.194 和 2.302 , 发展环境劣势中, 两个贫 困程度的农户的系数分别为 1.353 和 $0.784, \mathrm{P}$ 值均 小于 0.05 , 表明销售无保障、气象灾害、发展环境劣 势对不同程度贫困区分有显著影响。两种因素中, 一 般贫困发生比和普通贫困发生比之比分别是气象灾 害致贫之比的 $1.905 、 1.325$ 倍, 特别贫困发生比和 普通贫困发生比之比分别是气象灾害致贫之比的 2.302 和 1.012 倍, 表明销售无保障和发展环境劣势 对各程度贫困农户均有显著影响。

从外出务工风险来看, 工资拖欠对一般贫困农户 和特别贫困的系数分别为 0.675 和 $0.004, \mathrm{P}$ 值均小 于 0.05 , 说明工资拖欠对不同贫困程度的区分影响 较显著。工期无保障的影响系数对一般贫困和特别贫 困的系数为 0.842 , 显著性水平大于 0.05 , 说明工期 无保障对不同贫困程度的区分影响不显著。两种因素 对一般贫困和特别贫困发生比之比分别是气象灾害 致贫发生比之比的 2.121、1.037 和 0.325、0.824 倍, 说明外出务工拖欠工资致贫的发生比率比因外出务 工意外伤害致贫的比率高, 工资拖欠对各程度贫困有
显著影响, 工期无保障对各程度贫困影响不够显著。

从劳动技能水平来看, 劳动技能水平的高低与农 户贫困程度呈负相关。其中一般劳动技能水平对于一 般贫困农户的影响显著性大于 0.05 , 说明有无劳动 技能对一般贫困农户和普通贫困农户的区别不明显。 有无劳动技能对特别贫困农户的影响系数为 -0.023 , 且 $P<0.05$, 说明有无劳动技能对普通贫困和特别贫 困的区分影响显著。有一般劳动技能的贫困农户中, 一般贫困发生比和普通贫困发生比之比是无劳动技 能中的发生比的 0.108 倍，特别贫困发生比和普通 贫困发生比之比是无劳动技能发生比的 1.327 倍, 说 明有无劳动技能对一般贫困农户无显著影响, 对特别 贫困的农户有显著影响。在有特殊劳动技能水平的贫 困农户中,一般贫困发生比和普通贫困发生比之比是 无劳动技能之比的 1.156 倍 , 特别贫困发生比和普 通贫困发生比之比是无劳动技能之比的 1.038 倍, 说 明特殊劳动技能对各程度的贫困农户均有显著影响。

从健康水平来看, 健康的贫困人口中一般贫困的 系数是 -0.009 , 特别贫困的系数是 -0.365 , 相应的 $\mathrm{P}$ 值分别为 0.041 和 0.001 , 表明身体健康的贫困人 口对各程度贫困的区分有显著影响。身体残疾的贫困 劳动力中, 一般贫困和特别贫困的显著性水平均小于 0.05 , 说明身体残疾对于不同程度的贫困区别有显著 影响。身体健康的贫闲农户中, 一般贫困发生比和普 通贫困发生比之比是患有长期慢性病的贫困农户比 值的 0.612 倍, 特别贫困发生比和普通贫困发生比之 比是患有长期慢性病的贫困农户之比值的 1.325 倍, 说明身体健康对一般及以上程度的贫困有显著影响。 身体残疾的贫困农户中，一般贫困的发生比和普通贫 困发生比之比与患有大病的贫困农户的比值无明显 差别; 特别贫困的发生比和普通贫困的发生比之比是 患长期慢性病比值的 1.378 倍。该数据充分说明贫困 
程度与农户的健康状况有显著关系。

从教育水平看, 小学水平的一般贫困和特殊贫困 显著性水平分别大于 0.05 , 说明偏低的文化水平对 于贫困程度区分无显著影响。初中及以上水平对一般 贫困和特殊贫困显著性水平均小于 0.05 , 影响系数 分别为 -0.757 和 -0.096 , 说明越高的教育水平对贫 困程度的区分影响越显著。在小学水平的贫困农户中, 一般贫困发生比和普通贫困发生比之比是文盲或半 文盲水平的贫困发生之比的 0.012 倍, 特别贫困发生 比和普通贫困发生比之比是其比的 0.030 倍, 说明小 学及以下的教育水平对不同程度的贫困并无显著影 响。初中及以上的文化水平的贫困劳动力中, 一般贫 困发生比和普通贫困发生比之比是文盲或半文盲水 平的贫困发生之比的 1.376 倍, 特别贫困发生比和普 通贫困发生比之比是其比的 1.586 倍, 说明初中及以 上的教育水平对不同程度的贫困具有显著影响。

\section{4. 政策建议}

该研究地区的发展环境恶劣, 交通闭塞, 多个居 住地有塌陷风险, 稳产田地少等, 因此应积极改善当 地发展环境; 外出务工是当地农户增收的第二大途径, 应继续完善农民工外出保障措施, 维护农民工基本权 益; 特殊（高）劳动技能对农户的脱贫增收具有重要 意义。农户的健康状况与各贫困程度有显著关系, 因 此, 健康扶贫和完善的医疗保障措施对深度贫困地区 具有极大的促进作用, 提高地区教育水平对农户脱贫 具有重要意义。

因地制宜的 “特色农业+特色文化产业”、有效持 续的政策保障、灵活及时的保险支持, 三者结合才能 有效降低深度贫困风险, 单一的生产发展模式和政府 补占政策难以实现脱贫任务。深度贫困地区各种风险 因素聚集, 只有多策略齐下, 并对不同贫困程度的主 要致贫风险因素给以重视和适当的政策倾斜, 进行有 效的风险管理, 减轻致贫程度, 助力脱贫攻坚, 早日 实现乡村振兴。为此, 需要进一步开展如下工作:

\section{（1）产业扶贫}

特色农业扶贫。山村委会的种植环境易遭受自然 灾害, 如干旱、洪涝、泥石流、山体滑坡等, 加上土 地贫㾑, 全村有耕地中, 田 280.00 亩, 地 734.00 亩, 人均耕地只有 0.98 亩, 稳产和高产面积极少, 喜湿 作物难以生产,一般以核桃和玉米为主。保证从事第 一产业的劳动力在家能够稳产增收是降低贫困风险, 助力脱贫攻坚的重要工程。积极发掘地区特色和优势, 并将其转化为增收渠道是突破农村劳动力发展瓶颈 的必要方法。地区林木资源丰富, 地区核桃产量大,
质量好。因地制宜开发特色农业, 例如积极发展核桃 种植、林木开采、玉米产业发展等，由保险公司保障 种植前期、中期、后期，由政府带领打开销路，保障 市场价格，避免谷贱伤农的发生，确保农户收益，实 现农民增收; 以峨山丰富的森林资源为依托，农户还 可以开拓特色种植业, 比如草药种植、蘑菇种植等。

特色文化产业扶贫。峨山村委会的村寨以少数民 族一彝族为主，当地优秀的彝族文化传统已有 1700 多 年的悠久历史, 是极具社会价值的非物质文化遗产。 积极开发当地具有文化底蕴和精湛绚丽的特色文化 作为财富之路 (例如彝绣) 是解放农村劳动力的一种 重要途径。以彝绣为例, 农村彝族妇女多会彝绣, 开 发彝绣商业, 不仅能传承和弘扬彝绣文化, 更重要的 是能有效利用农村妇女劳动力, 增加家庭经济收入。 在精准扶贫的国家战略下积极开拓少数民族特色文 化产业，是民族文化的社会价值和经济价值的有效融 合。

\section{（2）产业政策保障}

农村产业难以壮大和进入市场的主要原因包括: 农村交通条件落后、市场信息不对称, 农户不能及时 了解市场的供求状况和市场价格, 因此出现一年物稀 价贵、一年谷贱伤农的不平衡现象，销路和价格无保 障是劳动力生产策略选择的最大风险因素。针对此情 况，政府在支持开发创业的同时要为农户前期发展铺 好路，为其开拓前期发展市场，寻找合适的销售方， 同时鼓励农户购买合适的农业保险, 为创业之路保驾 护航，降低劳动力致贫风险。总而言之，产业扶贫支 持不仅要做到前期发展有支持, 中期培养有补贴, 还 要做到后期销售有保障。草药种植业为例, 前期农户 通过小额贷款金融筹备资金，购买药材种子和设备， 村委会和政府调派技术特派员下乡指导农户培育技 术, 帮助寻找药材收购企业, 商谈价格, 签订合同等, 并对肥料和农药购买给与一定的补贴, 种植前可购买 一定的农业保险，以防自然灾害和气象灾害以及病虫 害导致农户亏损。

\section{（3）金融保险扶贫}

鼓励农户积极创业，发展特色养殖业、种植业、 旅游业等。由于贫困区劳动力的资金储备能力薄弱, 受经济条件限制, 很多农户想要创业但苦于资金无力 筹备。以内置金融保险创新重建利益为纽带，带动农 户自愿加入 “专业合作社+农业公司”, 创建扶贫利益 联合体，培养规模化种植养殖基地，形成 “统一金融 保险安排，统一生产结构区划，统一生产资料采购、 统一种植技术培训，统一田间管理和统一销售分红” 机制。金融保险创新解决了产前产中产后各环节风险, 保险提高了经济效益。 
因地制宜的保险扶贫授之以渔, 通过创新保险产 品, 保障生产保险与消费保险协同, 在生产端以资源 支持, 创建贫困地区的特色产业链。同时, 以防灾减 损项目向当地贫困户提供家门口的就业增收机会, 增 加非农收入。而且, 利用保险电商平台在消费端扶持, 建立联动消费扶贫机制, 化解了农户种植风险和价格 波动风险, 保障了农户收入稳定, 保险扶贫深入乡村 振兴细节, 强化因灾致（返）贫的保险扶贫效果。

另外, 创新 “大病保险+小额保险” 模式坚持 “愿 保尽保”, 推动扶贫小额保险提量扩面, 向困难群众 倾斜, 对建档立卡贫困人群降低起付线和提高赔付比 例, 实现大病医保 “二次赔付”。而且, 创新 “一站式 即时结算模式”，让贫困患者就医不需要付押金，出 院时仅需负担总疗的自付额, 其余报销范围内的医疗 不需要再进行垫付, 报销流程由原来 1-3 个月缩减至 五分钟以内, 实现患者出院一个窗口完成基本医保、 大病保险、民政救助、二次补偿、政府䚌底五条线的 报销流程。此模式建档立卡贫困患者住院医疗费用报 销比例达到 $90 \%$ 以上, 保险扶贫深入人心, 百姓生活 幸福美满, 强化了因病致（返）贫的保险扶贫效果。

\section{（4）教育扶贫}

在教育方面, 初中及以上的教育水平对不同程度 的贫困有显著影响。峨山村委会经济条件落后, 教育 水平相对非贫困地区较为落后。政府和当地村委会应 不断完善当地学校的教育软硬件设施, 为学生提供良 好的学习环境和优质的学习资源。在其他致贫风险因 素中, 一部分家庭因孩子上学而拮据, 依据政府教育 扶贫措施, 除了普及的扶贫政策, 还有对能读的、愿 意就读的孩子给与精神鼓励和经济支持, 保证农户学 子有书可读, 有书能读; 对于不愿意学的孩子, 要积 极引导参加技术教育培训活动, 提高劳动技能水平。

有无劳动技能对普通、一般、特别贫困的区分影 响显著, 特殊劳动技能对各程度的贫困农户均有显著 影响。峨山村委会是西部深度贫困民族地区的一个代 表, 当地剩余劳动力较多, 但劳动力整体技能水平偏 低, 市场就业和自主创业能力薄弱。当地政府应积极 响应国家政策, 进行劳动人口技能培训, 加大人力资 本投资, 着力提升劳动力技能素质, 把人口优势转化 为人力资源优势, 增加劳动人口脱贫增收的机会和能 力。

政府可根据村委会各村寨具体种植环境, 选取适 宜的农业生产策略, 调派专门的科技特派员下乡指导 种植、养殖技术, 提高劳动力技能水平, 大力发展生 产, 实现增收。

\section{（5）易地搬迁扶贫}

农业生产发展中, 发展环境劣势对农户贫困有显
著影响。峨山村委会位于三县边界, 当地少数民族村 寨居住环境差, 地势高峻, 且多为易塌陷地段, 要确 保农民长期居住环境安全稳定, 降低农村劳动力在外 风险, 提高农户的幸福感和安全感, 才能促进劳动力 高效生产发展。对于交通险、居住环境危险的村寨, 村委会和扶贫大队应积极实施异地搬迁扶贫, 选址建 设新农村工作, 改善地区发展环境, 实现交通和通信 村村通, 为早日实现乡村振兴打好坚实基础。

\section{（6）劳动力外出务工保障}

农村剩余劳动力丰富, 国家鼓励农村劳动力积极 外出务工，提高家庭经济收入。深度贫困民族地区的 农户受传统民族观念影响以及对陌生环境的排斥, 不 愿外出打工。但受自然环境和种植水平的限制, 农户 难以获得高收入实现脱贫致富。要提高农村劳动力外 出务工意愿, 需了解劳动力对外出务工的顾虑和需求, 并不断改进。由政府牵头, 商谈签订正规的劳务合同, 明确的工资和发放时间, 购买人生意外保险, 进行来 回接送和车费补贴等。贫困劳动力外出务工保障措施 落实是扶贫之路的一大法宝, 应不断完善当地劳动力 输出保障措施。

\section{致谢}

本文是北京高校高精尖学科 “战略经济与军民融 合”交叉学科 (GJJ2019163)、中央财经大学“一流学 科” 建设项目 “巨灾风险管理与自然灾害治理现代化 研究”、2020 年度国家民委民族研究项目 “后脱贫时 代西部藏区乡村振兴风险与内置金融研究 (2020GMB-030)”的阶段性研究成果。

\section{参考文献}

[1]西力艾里 - 要勒巴司. 新疆南疆三地州连片特困地区 多维贫困测度研究 [D]. 石河子大学, 2018.

[2] 孙梦瑶, 聂凤英. 西部贫困地区农户遭受各种冲击的状况及 对策 $[J]$. 贵州农业科学, 2017, 45(03) : 163-166.

[3]Yang Xiaoying. Analysis of the Problems in the Poverty Alleviation Work of Rural Industry and the Countermeasures [J]. China Collective Economy, 2019 (07) : 7-8.

[4]杨龙 等. 农业产业扶贫多维贫困瞄准研究 [J]. 中国人 口・资源与环境, 2019, 29 (02) : 134-144.

[5]王磊. 主要金融扶贫减贫模式及借鉴 $[J]$. 银行 家, 2019(04) : 119-120.

[6]余海燕. 精准扶贫与低保制度的协同共治研究 [J]. 农业 经济, 2019(03) : 74-75. 